\title{
PENGARUH PEMBERIAN KOMPRES HANGAT MEMAKAI PARUTAN JAHE MERAH (ZINGER OFFICINALE ROSCOE VAR RUBRUM) TERHADAP PENURUNAN SKALA NYERI PADA PENDERITA GOUT ARTHRITIS DI PANTI JOMPO YAYASAN GUNA BUDI BAKTI MEDAN TAHUN 2020
}

\author{
${ }^{1}$ Anita, ${ }^{2}$ Jenican Astanta, ${ }^{3}$ Boi Olifu Lafau, ${ }^{4}$ Tiarnida Nababan \\ ${ }_{1,2,3,4}$ Program Studi S-1 Keperawatan, Universitas Prima Indonesia, Indonesia \\ Email: 'anitapulungan0608@gmail.com, ${ }^{2}$ astantajenican.ja@gmail.com, ${ }^{3}$ boiperawat@gmail.com, \\ ${ }^{4}$ tiarnidan@yahoo.com
}

\begin{abstract}
ABSTRAK
Arthritis Gout suatu proses inflamasi yang terjadi karena deposisi kristal asam urat pada jaringan sekitar sendi (tofi). Nyeri gout arthritis dapat diatasi dengan terapi non farmakologi yaitu ompres jahe merah merupakan terapi non farmakologi yang dapat digunakan untuk mengurangi nyeri gout arthritis. Maka yang menjadi masalah dalam penelitian ini apakah ada pengaruh pemberian kompres hangat memakai parutan jahe merah (zingiber officinale roscoe van rubrum) terhadap penurunan skala nyeri pada penderita gout arthritis. Tujuan penelitian ini untuk mengetahui pengaruh pemberian kompres hangat memakai parutana jahe merah terhadap penurunan skala nyeri pada penderita gout arthritis di Panti Jompo Yayasan Guna Budi Bakti Medan. Jenis penelitian ini merupakan penelitian pre-eksperimen maka penelitian menggunakan rancangan one group pre-test dan post-test design yaitu kelompok dimana subyek di obervasi sebelum dilakukan intervensi, kemudian diobservasi lagi setelah dilakukan intervensi. Populasi dalam penelitian ini adalah seluruh penderita gout arthritis yang tidak mengkonsumsi terapi farmakologi jenis obat anti inflamasi di Panti Jompo Yayasan Guna Budi Bakti Tahun 2020 berjumlah 25 orang. Sampel diambil dengan menggunakan total sampling yaitu sebanyak 25 orang. Pengumpulan data menggunakan lembaran observasi. Analisa data menggunakan uji Wilcoxon sign rank test dengan signifikasi 0,05. Hasil penelitian uji Wilcoxon sign rank test pada hasil akhir didapat nilai $p=v a l u e ~ 0,000<\alpha=0,05$ sehingga dapat diambil. Kesimpulan bahwa adanya pengaruh pemberian kompres hangat memakai parutan jahe merah terhadap penurunan skala nyeri pada penderita gout arthritis. Saran untuk peneliti selanjutnya dapat meneliti pengaruh pemberian kompres hangat memakai parutan jahe merah pada penyakit lain seperti penyakit diabetes mellitus, gagal jantung, dan persendian.
\end{abstract}

Kata Kunci: Arthritis Gout, Kompres, Jahe Merah, Skala Nyeri.

\section{ABSTRACT}

Gouty arthritis is an inflammatory process that occurs due to the deposition of uric acid crystals in the tissues around the joints (TOFI). Gouty arthritis pain can be treated with non-pharmacological therapy, namely red ginger compress which is a non-pharmacological therapy that can be used to reduce gout arthritis pain. So the problem in this study is whether there is an effect of giving a warm compress using grated red ginger (zingiber officinale roscoe van rubrum) on reducing the pain scale in patients with gout arthritis. The purpose of this study was to determine the effect of giving warm compresses using red ginger parutana to reduce pain scale in patients with gout arthritis in Nursing Home Foundation Guna Budi Bakti Medan. This type of research is a pre-experimental research, the research uses a one-group pre-test and post-test design design, namely the group group where subjects are subjected to intervention before intervention, then observed again after intervention. The population in this study were all sufferers of gout arthritis who did not consume pharmacological therapy type of anti-inflammatory drugs in the Nursing Home Foundation Budi Guna Foundation in 2020 amounted to 25 people. Samples were taken using a total sampling of 25 people. Data collection uses observation sheets. Analysis of data using the Wilcoxon sign rank test with significance 0.05 . The results of the Wilcoxon sign rank test test results in the final results obtained $p$ value $=0,000<\alpha=0.05$ so that it can be taken. The conclusion that the effect of giving a warm compress using grated red ginger on the decrease in pain scale in patients with gout arthritis. Suggestions for further researchers can examine the effect of giving warm compresses using grated red ginger in other diseases such as diabetes mellitus, heart failure, and joints.

Keywords: Gouty Arthritis, Compresses, Red Ginger, Pain Scale. 


\section{PENDAHULUAN}

Menua adalah

menghilangnya secara perlahan-lahan kemampuan jaringan tubuh untuk memperbaiki diri dan mempertahankan struktur dan fungsi normalnya sehingga tidak dapat bertahan terhadap infeksi dan memperbaiki kerusakan yang diderita. Penyakit yang sering dialami lansia adalah hipertensi, rematik, gagal jantung, diabetes mellitus, gangguan fungsi ginjal, dan gangguan fungsi hati. Dan juga terdapat berbagai keadaan yang khas dan sering mengganggu lansia seperti ganguan fungsi kognitif, keseimbangan badan, pendengaran dan penglihatan (Sunarti dan Alhuda, 2018).

Menurut (World Health Organization, 2015) Angka kejadian gout arthritis mencapai $20 \%$ dari penduduk dunia yang telah terserang gout arthritis, dimana 5-10\% adalah mereka yang berusia 5-20 tahun dan $20 \%$ adalah mereka yang berusia 55 tahun. Berdasarkan hasil penelitian (Riskesdas, 2015) prevalensi nyeri gout arthritis di Indonesiaa mencapai $25,6 \%$ hingga 33,3\%, angkaaini menunjukkan bahwa nyeri akibat gout arthritis sudah sangat mengganggu aktivitas masyarakat Indonesiaa. Berdasarakan pusat data Provinsi Sumatra Utara 5,9\%. Angka kesakitan penduduk lanjut usia sebesar $26,93 \%$ artinya bahwa setiap 100 orang lanjut usia terdapat 27 orang diantaranya mengalami sakit. Kelompok usia yang mengalami nyeri gout arthritis biasanya pertama kai muncul pada usia 50 tahun, dan punya antara usia 60 tahun (Ningsih dan Lukman, 2009). Menurut data sendiri di Panti Jompo Yayasan Guna Budi Bakti Medan pada lansia yang mengalami gout arthritis sebanyak 73 penderita.

Arthritis Gout adalah suatu proses inflamasi yang terjadi karena deposisi kristal asam urat pada jaringan sekitar sendi (tofi). Gout juga merupakan istilah yang dipakai untuk sekelompok gangguan metabolik yang di tandai dengan meningkatnya konsentrasi asam urat (Misnadiarly, 2017). Arthritis Gout atau arthritis pirai adalah suatu peradangan sendi sebagai manifestasi dari akumulasi endapan krista monosodiumurt, yang terkumpul didalam sendi sebagai akibat dari tingginya kadar asam urat didalam darah (hiperurisemia). Tidak semua orang dengan hiperurisemia adalah penderita arthritis pirai atau sedang menderita arthritis pirai. Akan tetapi, resiko terjadi arthritis pirai lebih besar dengan meningkatnya konsentrasi asam urat darah. Penyakit ini dikaitkan dengan adanya abnormalitas kadar asam urat dalam serum darah dengan akumulasi endapan kristal monosodium urat yang terkumpul di dalam sendi. Keterkaitan antara gout dengan hiperurisemia yaitu produksi asam urat yang berlebihan, menurunnya sekskresi asam urat melalui ginjal, atau mungkin karena keduanya (Noor Zairin, 2016).

Nyeri gout arthritis dapat diatasi dengan terapi farmakologi dan non farmakologi. Kompres jahe merah merupakan terapi non farmakologi yang dapat digunakan untuk mengurangi nyeri gout arthritis. Adapun efek yang terdapat dalam kompres hangat jahe merah yaitu respon tubuh terhadap panas menyebabkan pelebaran pembuluh darah, menurunkan ketegangan otot, meningkatkan metabolisme jaringan. Pemberian kompres hangat jahe dapat memperbaiki sirkulasi darah dalam tubuh, dan mengurangi rasa nyeri (Susanto dan Fitriana, 2017). Jahe merah juga bisa mengurangi nyeri karena jahe merah memilikin kandungan senyawa gingerol dan shogoal yaitu senyawa panas dan pedas pada jahe merah yang memiliki sifat anti inflamasi non steroid, rasa pedas dari kompres hangat jahe merah akan mengurang peradangan, meredakan nyeri dan kaku (Savitri, 2016).

Berdasarkann jurnal penelitiann yang dilakukan oleh (Rusnoto, dkk, 2018). Teknik kompres hangat memakai jahe yaitu jahe merah 100 gram yang telah diparut diletakkan diatas washlap yang sudah dicelupkan pada air panas sekitar 500cc yang bersuhu sekitar $40^{\circ} \mathrm{C}$, setelah itu kompres pada daerah yang nyeri 20 menit selama 2 kali , yang dilakukan pada bulan Maret 2018 di Wilayah Kerja Puskesmas Alianyang Kota Pontianak. Hasil penelitiannya ada pengaruh kompres hangat jahe merah terhadap penurunan skala nyeri pada pasien gout arthritis. Selanjutnya penelitian yang dilakukan oleh Samsudin, 2016 diperoleh bahwa terdapat perbedaan nyeri pada pasien gout arthritis sebelum diberikan komprese hangat memakai parutan jahe merah dan sesudah diberikan kompres hangat memakai 
parutan jahe merah dengan didapat kesimpulan bahwa ada terdapat pengaruh yang disignifikan pemberian kompres hangat memakai parutan jahe merah terhadap penurunan skala nyeri pada penderita gout arthritis di Desa Tateli Dua, Kecamatan Mandolang, Kabupaten Minahasa. Selain itu, penelitian lain dilakukan oleh (Anna, dkk, 2016) didapatkan bahwa pemberian kompres jahe merah berpengaruh terhadap intensitas nyeri gout arthritis pada lansia.

Berdasarkan hasil wawancara dan pengambilan data yang dilakukan peneliti pada bulan Oktober 2019 diperoleh data bahwa penderita asam urat (gout arthritis) di Panti Jompo Yayasan Guna Budi Bakti Medan pada bulan Oktober tahun 2019 sebanyak 73 penderita. Yang tidak mengkonsumsi obat asam urat (gout arthritis) sebanya 25 penderita dan diantaranya berjenis kelamin laki-laki sebanyak 10 penderita dan berjenis kelamin perempuan sebanyak 15 penderita, serta menyatakan bahwa penderita merasakan sakit dibagian sendi, merasa tidak nyaman disekitar sendi dan tidak dapat melakukan kegiatan aktivitas seperti biasanya.

Berdasarkan hal tersebut peneliti tertarik untuk mengetahui pengaruh pemberian kompres hangat memakai parutan jahe merah (Zingiber Officinale Roscoe Van Rubrum terhadap penurunan skala nyeri pada penderita gout arthritis di Panti Jompo Yayasan Guna Budi Bakti Medan.

\section{METODE}

Jenis penelitian ini merupakan penelitian pre-eksperimen maka penelitian menggunakan rancangan one group pre-test dan post test design yaitu kelompok dimana subyek di obervasi sebelum dilakukan intervensi, kemudian di observasi lagi setelah dilakukan intervensi, waktu penelitian dilakukan pada bulan Maret 2020 (Sugiyono, 2018).

Populasi dalam penelitian ini adalah seluruh penderita gout arthritis yang tidak mengkonsumsi terapi farmakologi jenis obat anti inflamasi di Panti Jompo Yayasan Guna Budi Bakti Tahun 2020 berjumlah 25 orang. Karena jumlah populasi kurang dari 30 orang maka teknik pengambilan sampel pada penelitian ini dilakukan secara Total Sampling. Total sampling adalah teknik penentuan sampel bila semua anggota populasi digunakan sebagai sampel. Jadi jumlah sampel pada penelitian inip sebanyak 25 orang.

Metode pengumpulan data dalam penelitian ini menggunakan data primer dan sekunder yang diperoleh secara langsung maupun data dari instansi terkait sehingga teknik pengumpulan data yang dilakukan dalam penelitian ini adalah lembaran observasi menggunakan skala nyeri VAS (Visual Analog Scale).

Analisa penelitian ini menggunakan analisa univariat dan analisa bivasiat. Analisa univariat yaitu dilakukan terhadap variabel yang telah diteliti dimana setiap variabel dibuat gambaran distribusi dan presentasi. Analisa bivariat yaitu dilakukan untuk mengetahui pengaruhh antara variabel independen dengan variabel dependen dengan menggunakan uji paired t-test jika data berdistribusi normal dan menggunakan uji Wilcoxon Sign Rank Test jika data tidak berdistribusi normal pada program SPSS (Statistical Produc and Service Solutionso). Dengan tingkat kepercayaan $95 \%$, Ha di terima jika nilai $p<0,05$ berarti ada pengaruh antara dua variabel yang diteliti, Ha diterima apabila $p>0,05 \mathrm{Ha}$ diterima (Ho ditolak) maka artinya tidak ada pengaruh.

\section{HASIL DAN PEMBAHASAN \\ 3.1 Hasil}

Hasil penelitian diuraikan mengenai pengaruh pemberian kompres hangat memakai parutan jahe merah (zinger officinale roscoe var rubrum) terhadap penurunan skala nyeri pada penderita gout arthritis di panti jompo yayasan guna budi bakti medan tahun 2020.

Tabel 1. Karakteristik Distribusi Responden Menurut Jenis Kelamin dan Umur di Panti Jompo Yayasan Guna Budi Bakti Medan Tahun 2020

\begin{tabular}{ccc}
\hline $\begin{array}{c}\text { Karakteristik } \\
\text { Distribusi } \\
\text { Responden }\end{array}$ & $\begin{array}{c}\text { Jumlah } \\
(\mathbf{n})\end{array}$ & $\begin{array}{c}\text { Persentase } \\
(\mathbf{\%})\end{array}$ \\
\hline Jenis Kelamin & & \\
\hline Laki-laki & 10 & 40 \\
\hline Perempuan & 15 & 60 \\
\hline Total & $\mathbf{2 5}$ & $\mathbf{1 0 0}$ \\
\hline Umur & & \\
\hline 60-70 Tahun & 9 & 36 \\
\hline
\end{tabular}




\begin{tabular}{ccc}
\hline 71-80 Tahun & 9 & 36 \\
\hline $81-90$ Tahun & 7 & 28 \\
\hline Total & $\mathbf{2 5}$ & $\mathbf{1 0 0}$ \\
\hline Sumber: Data Primer, 2020
\end{tabular}

Dari data tabel 1 karakteristik jenis kelamin responden diatas diperoleh jenis kelamin laki-laki dengan jumlah 10 responden (40\%) dan perempuan dengan jumlah 15 responden (60\%). Dari data karakteristik umur responden diatas diperoleh umur dengan rentang 60-70 tahun dengan jumlah 9 responden (36\%), 71-80 tahun dengan jumlah 9 responden (36\%), 81-90 tahun dengan jumlah 7 responden $(28 \%)$.

Tabel 2. Distribusi Responden Menurut Skala Nyeri Pre-test (Sebelum) Dilakukan

Pemberian Kompres Hangat Memakai

Parutan Jahe Merah di Panti Jompo Yayasan

Guna Budi Bakti Medan Tahun 2020

\begin{tabular}{ccc}
\hline Skala nyeri & $\begin{array}{c}\text { Jumlah } \\
(\mathbf{n})\end{array}$ & $\begin{array}{c}\text { Persentase } \\
(\mathbf{\%})\end{array}$ \\
\hline $\begin{array}{c}\text { Skala nyeri } \\
\text { ringan }\end{array}$ & 6 & 24 \\
\hline $\begin{array}{c}\text { Skala nyeri } \\
\text { sedang }\end{array}$ & 5 & 20 \\
\hline $\begin{array}{c}\text { Skala nyeri } \\
\text { berat }\end{array}$ & 14 & 56 \\
\hline Total & $\mathbf{2 5}$ & $\mathbf{1 0 0}$ \\
\hline
\end{tabular}

Sumber: Data Primer, 2020
Dari tabel diatas diperoleh data skala nyeri responden pre-test (sebelum) dilakukan pemberian kompres hangat memakai parutan jahe merah dengan mayoritas responden memiliki skala nyeri 14 responden $(56 \%)$.

Tabel 3. Distribusi Responden Menurut Skala Nyeri Pros-tes ( Sesudahn) Dilakukan

Pemberian Kompresm Hangat Memakai Parutan Jahe Merah di Panti Jompo Yayasan Guna Budi Bakti Medan Tahun 2020

\begin{tabular}{|c|c|c|}
\hline Skala nyeri & $\begin{array}{c}\text { Jumlah } \\
\text { (n) }\end{array}$ & $\begin{array}{c}\text { Persentase } \\
(\%)\end{array}$ \\
\hline $\begin{array}{l}\text { Skala nyeri } \\
\text { ringan }\end{array}$ & 17 & 68 \\
\hline $\begin{array}{l}\text { Skala nyeri } \\
\text { sedang }\end{array}$ & 6 & 24 \\
\hline $\begin{array}{c}\text { Skala nyeri } \\
\text { berat }\end{array}$ & 2 & 8 \\
\hline Total & 25 & 100 \\
\hline $\begin{array}{l}\text { Sumber } \\
\text { Dari tabel } \\
\text { eri responden } \\
\text { mberian } \\
\text { utan jahe m } \\
\text { ponden me } \\
\text { anyak mas }\end{array}$ & $\begin{array}{l}\text { Data Prim } \\
\text { atas diper } \\
\text { st-test (se } \\
\text { apres } \\
\text { h dengan } \\
\text { iki skala } \\
\text { itas } \quad 68\end{array}$ & $\begin{array}{l}2020 \\
\text { leh data skala } \\
\text { dah) dilakukan } \\
\text { ngat memakai } \\
\text { mayoritas } \\
\text { nyeri ringan } \\
\text { responden }\end{array}$ \\
\hline
\end{tabular}

Tabel 4. Pengaruh Pemberian Kompres Hangat Memakai Parutan Jahe Merah (Zinger Officinale Roscoe Var Rubrum) Terhadap Penurunan Skala Nyeri Pada Penderita Gout Arthritis Di Panti Jompo Yayasan Guna Budi Bakti Medan Tahun 2020

\begin{tabular}{ccccc}
\hline Variabel & Shapiro-wilk & Variabel & Mean Rank & p-value \\
\cline { 2 - 3 } & Sig & & \\
\hline Pre-Test & 0,000 & Skala Nyeri & 8,50 & 0,000 \\
\hline Post -Test & 0,000 & & 0,00 & \\
\hline \multicolumn{5}{c}{ Sumber : Data Primer , 2020 }
\end{tabular}

Dari tabel 4 diatas menujukan hasil uji normalitas dengan menggunakan metode normalitas Shapiro-wilk dimana data responden pada data pre-test memilikii nilaii sig $0,000<0,05$ pada data post-test memiliki nilai sig $0,000<0,05$. Uji Wilcoxon Signe Rank Tes memiliki nilai Mean Rank pretestposttest sebesar 8,50-0,00 dengan p-value 0,000 .

\subsection{Pembahasan}

Pembahasan menjelaskan hasil penelitian mengenai pengaruh pemberian kompres hangat memakai parutan jahe merah (zinger officinales sroscoe car rubrum) terhadap penurunan skala nyeri pada penderita gout arthritis di Panti Jompo Yayasan Gunag Budi Bakti Medan Tahun 2020 dengan responden 25 sebagai sampel.

Pada tabel 2 distribusi responden nenurut skala nyeri Pre-test (Sebelum) dilakukan pemberian kompres hanga memakai parutan jahe merah di Panti Jompo Yayasan Guna Budi Bakti Tahun 2020, dengan mayoritas responden memiliki skala nyeri berat sebanyak 14 responden dengan persentase 56\%. Kemudian diikutin oleh responden dengan skala nyeri ringan 
sebanyak 6 responden dengan persentase $24 \%$ dan reponden dengan skala nyeri sedang sebanyak 5 responden dengan persentase $20 \%$.

Penelitian ini sama dengan penelitian yang dilakukan oleh (Rima, dkk, 2018) dengan judul Pengaruh Pemberian Kompres Jahe Merah Terhadap Penurunan Nyeri Pada Pasien Gout Arthritis Di Wilayahh Kerja Puskesmas Alianyang Kota Pontianak, menyatakan bahwa sebelum dilakukan intervensi dilakukan pengukuran skala nyeri terlebih dahulu, responden paling banyak mengalamin nyeri sedang.

Pada tabel 3 distribusi responden menurut skala nyeri Post-test (Sesudah) dilakukan pemberian kompres hangat memakai parutan jahe merah di Panti Jompo Yayasan Guna Budi Bakti Tahun 2020, dengan mayoritas responden memiliki skala nyeri ringan sebanyak 17 responden dengan persentase $68 \%$. Kemudian diikutin oleh responden dengan skala nyeri ringan sebanyak 6 responden dengan persentase $24 \%$ dan responden dengan skala nyeri sedang sebanyak 2 responden dengan persentase $8 \%$.

Penelitian ini menujukan terjadinya penuruan skala nyeri pada responden setelah dilakukan pemberian kompres hangat memakai jahe merah selama 7 hari berturutturut, hal ini sama dengan hasil penelitian yang dilakukan (Rima, dkk, 2018) pada kelompok intervensi yang memiliki pengaruh penurunan skala nyeri dengant $p$ value $=0,000$ hal ini juga sama pada hasil penelitian yang dilakukan oleh (Anna, dkk, 2016) dengan efektivitas memberikan kompres hangat memakai jahe merah pada lansia menyatakan ada penurunan gout arthritis, penurunan gout arhtritis ini akan berdampak pada skala nyeri yang dialamin oleh lansia.

Pada tabel 4 menujukan hasil uji normalitas dengan menggunakan metode normalitas Shapiro-wilk ada data responden pada data pre-test memiliki nilai sig $0,000<0,05$ maka diatas tidak berdistribusi normal, begitu juga dengan data post-test memiliki nilai sig $0,000<0,05$ maka data tidak berdistribusi normal dengan hasil uji tersebut. Dan data tidak berdistribusi normal, sehingga analisa data yang digunakan dalam penelitian ini adalah Uji Wilcoxon Signed Rank Tes memiliki nilai Mean Rank pre test- pro test sebesar 8,50-0,00 dengan $\mathrm{p}$-value 0,000 . Hal ini sama juga dilakukan dalam penelitian (Rima, dkk, 2018) yang menggunakan uji Wilcoxon signe Rank Tes untuk mengetahui pengaruh kompres hang at jahe merah terhadap penurunan skala nyeri pada pasien penderita gout arthritis di Wilayah Kerja Puskesmas Alianyang Kota Pontianak.

Berdasarkan hasil uji Wilcoxon Signe Rank Tes data yang digunakan adalah hasil pengukuran skala nyeri sebelum dilakukan pemberian kompres hangat jahe merah pada hari pertama penelitian, dan hasil pengukuran skala nyeri sesudah dilakukan pemberian kompres hangat jahe merah pada hari terakhir penelitian dengan nilai Mean Rank Pre testPost test sebesar 8,50-0,00 dengan $\mathrm{p}$ value 0,000 .

Berdasarkan data diatas dapat disimpulkan bahwa ada pengaruh pemberian kompres hangat jahe merah terhadap penurunan skala nyeri pada penderita gout arthritis hal ini ditujukan dengan $\mathrm{p}$ value $0,000<0,05$ sehingga $\mathrm{Ha}$ diterima dan Ho ditolak.

Pemberian kompres hangat jahe merah yang mempunyai kandungan pati, minyak atsiri dan ekstrak yang larut dalam alkohol. Menurut (Stoilovaa, 2007) mengatakan beberapa komponen kimia jahe, seperti gingonel, shogaol dan zinggerone memberikan efek farmakologi dan fisiologi seperti antioksidasi, anti inflamasi, analgesik, antikarsinogenik, non toksik dan non mutagenik (Hernani \& Winarti, 2014).

Setelah diberikan inetervensi melakukan pemberian kompres jahe merah kepada responden mengalami penurunan skala nyeri. Memberikan kompres jahe merah sebagai terapi komplementer sangatlah baik kepada lansia karena bahan yang digunakan adalah bahanm yang sangat alami dan tidak memiliki efek samping, jahe merah serta pengolahannya sangat mudah dilakukan.

\section{KESIMPULAN}

Berdasarkan hasil pengukuran setelah dilakukan pemberian kompres hangat memakai parutan jahe merah skala nyeri yang dialami mayoritas reponden dengan kategori skala nyeri ringan. Dari data diatas dapat menunjukkan bahwa ada pengaruh terhadap pemberian kompres hangat memakai 
hparutan jahe merah terhadap penurunan skala nyeri pada pasien gout arthritis di Panti Jompo Yayasan Guna Budi Bakti Medan Tahun 2020.

\section{REFERENCES}

Alhuda dan Sunarti (2018). Pengaruh Kompres Hangat Jahe Merah Terhadap Penurunan Skala Nyeri Artritis Reumatoid Pada Lansia. Jurnal Kesehatan Priority, 1 (1), 2614-4719.

Anna, Rina \& Franly. 2016. Pengaruh Pemberian Kompres Hangat Memakai Parutan Jahe Merah (Zingiber Officinale Roscoe Vas Rubrum) Terhadap Penurunan Skala Nyeri Pada Penderita Gout Artritis Di Desa Tateli Dua Kecamatan Mandolang Kabupaten Minahasa. eJornal Keperawatan (e-Kp) 4 (1).

Arman Eliza, dkk. (2018). Pengaruh Kompres Hangat Jahe Mehar Terhadap Rasa Nyeri Pada Pasien Rheumathoid Arthritis. Jurnal Kesehatan Medika Saintika. Volume 10 Nmor 2. https://jurnal.syedzasaintika.ac.id.

Fitriana, dkk. (2017). Kebutuhan Dasar Manusia: Teori dan Aplikasi Dalam Praktik Keperawatan. Yogyakarta: Pustaka Baru Press.

Hernani dan Winarti, C., 2014. Kandungan Bahan Aktif Jahe dan Pemanfaatannya Dalam Bidan Keehatan, Diakses dari https://balittro.litbang.pertanian.go.id.

Jiwantoro, YA. 2017. Riset Keperawatan Analisis Data Statistik Menggunakan SPSS. Jakarta : Mitra Wacana Media.

Misnadiarly. 2017. Rematik : Asam UratHiperurisemia, Arthritis Gout Ed.2. Pustaka Obor Populer. Jakarta.

Ningsih N, \& Lukman., 2009. Asuhan
Keperawatan pada Klien dengan Gangguan Sistem Mukloskeletal. Jakarta: Salemba Medika.

Noor, Zairin. 2016. Buku Ajar Ganggan Muskuloskeletal Edisi 2. Jakarta: Salemba Medika.

Notoatmodjo Soekidjo. 2017. Metodologi Penelitian Kesehatan. Jakarta: Rineka Cipta.

Rima, Dkk. 2018. Pengaruh Pemberian Kompres Jahe Merah Terhadap Nyeri Pda Pasien Gout Arthritis Di Wilayah Kerja Puskesmas Alianyang Kota Pontianak. Universitas Tanjungpura.

Rusnoto. Noor, C. Indah, R. 2018. Pemberian Kompres Hangat Memakai Jahe Untuk Meringankan Skala Nyeri Pada Pasien Asam Urat di Desa Kedung Wungu Kecamatan Tegowanu Kabupaten Grobogan. JIKK. Vol 6 No. 1. 29-39.

Samsudin. 2016. Pengaruh Pemberian Kompres Hangat Memakai Parutan Jahe Merah Terhadap Penurunan Skala Nyeri Pada Penderita Gout Arthritis di Desa Tateli Dua Kecamatan Mandolang Kabupaten Minahasa. eJournal Kep Volume 4. Nomer 1.

Savitri, Astrid. 2016. Tanaman Ajaib Basmi Penyakit Dengan TOGA (Tanaman Obat Keluarga). Depok: Bibit Publisher.

Sugiyono. 2018. Metode Penelitian Pendidikan Pendekatan Kuantitatif, kualitatif, dan R\&D. Bandung: Alfabeta.

Susanto, Vita Andina \& Yuni Fitriani. 2017. Kebutuhan Dasar Manusia: Teori dan Aplikasi Dalam Praktik Keperawatan. Yogyakarta: Pustaka Baru Press.

Sutrisno. 2015. Pengantar Peraktikum Komputer. Pusat Komputer dan Bahasa. Sumatra Utara. 